\title{
Defined plant extracts can protect human cells against combined xenobiotic effects
}

\author{
Céline Gasnier ${ }^{1,2}$, Claire Laurant ${ }^{3}$, Cécile Decroix-Laporte ${ }^{3}$, Robin Mesnage ${ }^{1,2}$, Emilie Clair ${ }^{1,2}$, \\ Carine Travert', Gilles-Eric Séralini ${ }^{1,2^{*}}$
}

\begin{abstract}
Background: Pollutants representative of common environmental contaminants induce intracellular toxicity in human cells, which is generally amplified in combinations. We wanted to test the common pathways of intoxication and detoxification in human embryonic and liver cell lines. We used various pollutants such as Roundup residues, Bisphenol-A and Atrazine, and five precise medicinal plant extracts called Circ1, Dig1, Dig2, Sp1, and Uro1 in order to understand whether specific molecular actions took place or not.
\end{abstract}

Methods: Kidney and liver are major detoxification organs. We have studied embryonic kidney and hepatic human cell lines E293 and HepG2. The intoxication was induced on the one hand by a formulation of one of the most common herbicides worldwide, Roundup 450 GT+ (glyphosate and specific adjuvants), and on the other hand by a mixture of Bisphenol-A and Atrazine, all found in surface waters, feed and food. The prevention and curative effects of plant extracts were also measured on mitochondrial succinate dehydrogenase activity, on the entry of radiolabelled glyphosate (in Roundup) in cells, and on cytochromes P450 1A2 and 3A4 as well as glutathione-Stransferase.

Results: Clear toxicities of pollutants were observed on both cell lines at very low sub-agricultural dilutions. The prevention of such phenomena took place within $48 \mathrm{~h}$ with the plant extracts tested, with success rates ranging between 25-34\% for the E293 intoxicated by Roundup, and surprisingly up to 71\% for the HepG2. By contrast, after intoxication, no plant extract was capable of restoring E293 viability within 48 h, however, two medicinal plant combinations did restore the Bisphenol-A/Atrazine intoxicated HepG2 up to 24-28\%. The analysis of underlying mechanisms revealed that plant extracts were not capable of preventing radiolabelled glyphosate from entering cells; however Dig2 did restore the CYP1A2 activity disrupted by Roundup, and had only a mild preventive effect on the CYP3A4, and no effect on the glutathione S-transferase.

Conclusions: Environmental pollutants have intracellular effects that can be prevented, or cured in part, by precise medicinal plant extracts in two human cell lines. This appears to be mediated at least in part by the cytochromes P450 modulation.

\section{Background}

Biochemical activities are generally detailed per compound in cellular research, although human cells are exposed daily to mixtures of xenobiotics and plant compounds. However, medicinal extracts may be claimed to prevent or cure chemical intoxications, but few of these are tested for their mechanisms of actions or cellular impacts. With a view to tackle this issue, we have first

\footnotetext{
* Correspondence: criigen@unicaen.fr

'Laboratory of Biochemistry EA2608, Institute of Biology, University of Caen, France

Full list of author information is available at the end of the article
}

characterized the mechanisms of intoxication of two human cell lines with mixtures of common environmental pollutants. One of them is Roundup (R), the most widely used herbicide worldwide, the residues of which are common in surface waters [1]. These residues also enter the food chain [2], even through genetically modified edible plants [3]. $\mathrm{R}$ is made up from a mixture of an isopropylamine salt of glyphosate $(\mathrm{G})$, quantitatively a minor compound, and various specific adjuvants depending on the formulation [4]. We have previously characterized some toxic effects and their pathways for several $\mathrm{R}$ formulations, and endocrine disrupting actions
C Biomed Central

() 2011 Gasnier et al; licensee BioMed Central Ltd. This is an Open Access article distributed under the terms of the Creative Commons Attribution License (http://creativecommons.org/licenses/by/2.0), which permits unrestricted use, distribution, and reproduction in any medium, provided the original work is properly cited. 
at nontoxic levels. This was proved with human cell lines JEG3, E293, HepG2, Hep3B, and fresh umbilical cord or placental cells [5-9]. The second xenobiotic mixture of Bisphenol-A (BPA) and Atrazine (Az) is from products commonly found in the environment; BPA, a plastic compound found in the food chain, and Atrazine a major herbicide with its derivatives (also in surface waters) the toxicity of which we have studied alone [10]. In the present study, we chose the human embryonic kidney cell line E293, for the intoxication/detoxification models, because it represents a very sensitive model, and then HepG2, as it is one of the most well known and available cell lines derived from the human liver, which is the major detoxification organ on a par with the kidneys. Moreover HepG2 cells are characterized for xenobiotic metabolism enzymes, mainly cytochromes P450 CYP1A2, CYP3A4, and glutathione S-transferase (GST), [11-13] measured in this work.

Detoxifying mechanisms are frequently claimed to be enhanced by plant extracts $[14,15]$. We have tested the ability of 5 newly characterized drugs, Circ1, Dig1, Dig2, Sp1 and Uro1 to protect or cure human cells before or after intoxication. The composition of each drug was previously developed by Sevene Pharma Company and is represented in Table 1. According to the scientific literature, the protective properties of the plants involved are very large. For instance, some herbal extracts of Circ1 can be hepatoprotective $[16,17]$. Some Sp1 compounds not only feature anti-mutagenic activities, but also provide a protection against oxidative stress, as well as antitumor and anti-inflammatory effects [18-20]. Among others, the herbal extracts of Uro1 have anti-

Table 1 Plant composition of preventive and/or curative products

\begin{tabular}{cc}
\hline Products & Plant extracts \\
\hline Dig1 & $\begin{array}{c}\text { Taraxacum officinalis } \\
\text { Arctium lappa } \\
\text { Berberis vulgaris }\end{array}$ \\
\hline Dig2 & Chelidonium majus \\
& Rhamnus frangula \\
& Raphanus sativus \\
\hline \multirow{2}{*}{ Circ1 } & Carduus marianus \\
& Pulsatilla vulgaris \\
& Berberis vulgaris \\
\hline \multirow{2}{*}{ Sp1 } & Pulsatilla vulgaris \\
& Sambucus nigra \\
& Rumex crispus \\
\hline \multirow{2}{*}{ Uro1 } & Spirea ulmaria \\
& Solidago virgaurea \\
& Capsella bursa pastoris
\end{tabular}

These 70\% alcohol plant extracts were accurately elaborated by Sevene Pharma according to present medical knowledge. inflammatory, anti-oxidative and anti-microbial activities [21-23]. However, the combined effects of the new drugs have never been tested at the cellular level. We focused here on Dig1 and particularly Dig2 for the potential of digestive detoxification or hepato-protective synergistic effects provided by some of their compounds [24-29]. It was therefore quite interesting to compare these general findings on plant extracts to some biochemically precise markers that could be modified in human hepatocytes, such as cytochromes P450, glutathione S-transferase (GST), and first of all in cellular viability studies on mitochondrial succinate dehydrogenase (SD). This could enable us to understand the action pathways of these mixtures used as medicinal plants in vivo.

\section{Methods}

\section{Chemicals}

The $\mathrm{R}$ formulation used was Roundup GT $+{ }^{\circledR}$ (Monsanto, Anvers, Belgium) at $450 \mathrm{~g} / \mathrm{l}$ of $\mathrm{G}$, product number 2020448 available on the market. Dilutions were prepared in Eagle's modified minimum essential medium (EMEM; Abcys, Paris, France), supplemented with 10\% calf fetal serum from Cambrex (Verviers, Belgium) or otherwise indicated. $G^{*}$ was radiolabelled by PerkinElmer (Courtaboeuf, France), and has a specific activity of $55 \mathrm{mCi} / \mathrm{mmol}$. Dig1, Dig2, Sp1, Uro1 and Circ1 are mixtures of diluted organic plant extracts (Table 1) obtained by Sevene Pharma (Monoblet, France) from original independent macerates. These were diluted in $70 \%$ alcohol. Each solution was prepared in EMEM at 2\% of the mixture in positive controls. Bisphenol A (BPA, lot 239658), Atrazine (Az, lot 49085), 3-(4,5-Dimethylthiazol-2-yl)-2,5-diphenyl tetrazolium bromide (MTT) and all other compounds, unless otherwise specified, were from Sigma-Aldrich (Saint Quentin Fallavier, France). $\mathrm{BPA}$ and $\mathrm{Az}$ were prepared in 0.5\% DMSO then diluted in serum-free EMEM and adjusted at $\mathrm{pH}$ 7.4. The MTT stock solution at $5 \mathrm{mg} / \mathrm{ml}$ in phosphate-buffered saline was diluted 10-fold in serum-free EMEM and filtered through a $0.22 \mu \mathrm{m}$ filter before each use.

\section{Cell cultures, Roundup and/or Plant Extract Exposures}

The hepatoma cell line HepG2 was provided by ECACC, number 85011430. The cells were isolated from a 15 year-old Caucasian boy. The embryonic kidney 293 cell line (ECACC, number 85120602) was provided by CERDIC (Sophia-Antipolis, France). Cells were grown in flasks of $75 \mathrm{~cm}^{2}$ surface from Dutscher (Brumath, France) in medium (M) containing phenol red-free EMEM with $2 \mathrm{mM}$ glutamine, $1 \%$ non-essential amino acid, $100 \mathrm{U} / \mathrm{ml}$ of antibiotics (mix of penicillin, streptomycin, kanamycin) and $10 \%$ fetal calf serum. For treatments, 50,000 cells were plated per well or in flasks depending on the assay (see below), and grown at $37^{\circ} \mathrm{C}$ 
(5\% $\mathrm{CO}_{2}, 95 \%$ air) over a period of $48 \mathrm{~h}$ to $80 \%$ confluence in 48-well plates (except for $G$ * treatment, which was conducted with 24-well plates). The cells were then exposed to various concentrations of tested products, the media were changed every 24 hours.

\section{Cell viability assay}

The mitochondrial succinate dehydrogenase activity in cells was measured by the MTT test, based on the cleavage of MTT into blue formazan [30,31], adapted in our group by Auvray et al. [32]. The optical density was measured using a luminometer (Mithras LB 940, Berthold, France) at $570 \mathrm{~nm}$. The toxicity was obtained after $\mathrm{R}$ or BPA-Az treatments. The protective actions were evaluated by incubations of plant extracts $(\mathrm{X})$ before toxic treatments, and the curative effects after toxic treatments. Protective efficiencies (from LC50 considered as zero efficiency) were calculated by the formulations at 24 h: $100-[(100-X R$ viability $) \times 100 /(100-R$ viability) $]$ and at $48 \mathrm{~h}: 100-[(100-\mathrm{XXR}$ viability $) \times$ $100 /(100$ - R viability)]. Curative effects are calculated for $24 \mathrm{~h}$ by the difference RX - RM or RXX - RMM for $48 \mathrm{~h}$, or accordingly up to $96 \mathrm{~h}$.

\section{Cell entry of ${ }^{14} \mathrm{C}$-Glyphosate $\left(\mathrm{G}^{*}\right)$}

In order to measure the $G$ entry into cells with or without adjuvants of R, HepG2 confluent cells were exposed to $\mathrm{R}$ at $0.01 \%$ (24-well plates, $500 \mu \mathrm{l} /$ well). $\mathrm{G}^{*}$ was added in serumfree EMEM at a final concentration of $0.266 \mu \mathrm{mol} / \mathrm{ml}$ for a specific activity of $55 \mu \mathrm{Ci} / \mu \mathrm{mol}$, corresponding to the quantity of $\mathrm{G}$ in $0.01 \%$ of $\mathrm{R}$ (not significantly toxic in these conditions). Dig1 or Dig2 were added to cells at $2 \%$, proven to be nontoxic, before or after $\mathrm{G}^{*}$ and R. Attached cells were then washed 3 times with a PBS solution, lysed by crushing after freezing cycles and the radioactivity was counted with $1.4 \mathrm{ml}$ scintillant liquid (Ultima Gold 6013329 in $6 \mathrm{ml}$ polyethylene tubes in Packard counter 1600LR, USA). The amount of ${ }^{14} \mathrm{C}$-Glyphosate $\left(G^{*}\right)$ entered in cells was measured in \% by counting the radioactivity in pellets, and taking into account the mortality $(20 \%$, as in controls, measured by MTT test) according to the formula [ $\mathrm{G}^{*}$ in pellets $\times(120 / 100)] \times 100 / G^{*}$ in supernatants.

\section{Cytochrome activities}

The best protective or curative compound Dig2 (for R or BPA-Az, respectively) was chosen to study cytochrome (CYP) activity. The HepG2 cell line was amplified around $80 \%$ confluence and cells were plated at $86 \times 10^{3}$ cells/ $\mathrm{cm}^{2}$ in 3 flasks of $175 \mathrm{~cm}^{2}$ for each point. $\mathrm{R}$ (final non toxic concentration $0.0157 \%$ ) was incubated before or after Dig2 or medium (M) alone, by changing the medium every 24 hours. At the end of the incubation time, cells were collected, counted and stored at $-80^{\circ} \mathrm{C}$. Then, S9 fractions (membrane and cytosolic enzymes) were prepared for each treatment. The medium was removed, and cells dislodged by treatment with $7 \mathrm{ml}$ of trypsinEDTA (Lonza, France) and washed (PBS, Eurobio, France) twice by centrifugations (70 $\mathrm{g}, 5 \mathrm{~min}$ ), at room temperature. Cells were then resuspended in $500 \mu \mathrm{l}$ of $50 \mathrm{mM}$ phosphate buffer $\mathrm{pH} 7.5$ with $0.25 \mathrm{M}$ sucrose, 1 mM DTT, homogenized and centrifuged at 9,000 $\mathrm{g}$, at $4^{\circ} \mathrm{C}$ for $30 \mathrm{~min}$. The supernatants corresponding to the $\mathrm{S} 9$ fractions were collected and frozen at $-80^{\circ} \mathrm{C}$ until further evaluation for enzymatic activities. Protein concentration was determined in each S9 fraction according to the Bicinchoninic Acid Protein Assay (Sigma, France).

The cytochrome P450 CYP1A2 and CYP3A4 activities were quantified by the P450 $\mathrm{Glo}^{\mathrm{TM}}$ assays (V8771, Batch 271384 and V8801, Batch 277348, respectively; Promega, France). Each $2 \mathrm{X}$ Cytochrome $\mathrm{P} 450 / \mathrm{KPO}_{4} /$ Substrate Reaction mixtures containing the $\mathrm{S} 9$ fractions were preincubated at $37^{\circ} \mathrm{C}$ for $10 \mathrm{~min}$ in white 96-well plates (655075, Batch 08340329, Dutscher, France). The enzymatic reaction was initiated by adding $25 \mu \mathrm{l}$ of $2 \mathrm{X}$ $\mathrm{NADPH}$ regenerating system to each well. The plate was then incubated at $37^{\circ} \mathrm{C}$ for $20 \mathrm{~min}$ for CYP1A2; $30 \mathrm{~min}$ for CYP3A4. The reconstituted Luciferin Detection reagent $(50 \mu \mathrm{l})$ was added before mixing $10 \mathrm{sec}$ and incubating at room temperature for $90 \mathrm{~min}$ in order to stabilize the luminescent signal. The luminescence was then read with a luminometer (Veritas Turner Biosystems, France). Three independent experiments were performed from three batches of fraction S9.

\section{GST activity}

The protocol was adapted from Habig et al. [33]. Briefly, $160 \mu \mathrm{g}$ of the human liver S9 fraction (positive control) or $320 \mu \mathrm{g}$ of S9 cell fractions were mixed with $10 \mu \mathrm{l}$ of $100 \mathrm{mM}$ GSH and $990 \mu \mathrm{l}$ phosphate buffer in duplicate. Reduced L-glutathione (GSH) was dissolved in deionized water; a $\mathrm{pH} 6.5$ buffer was prepared by mixing 0.7 volume of $0.1 \mathrm{M} \mathrm{KH}_{2} \mathrm{PO}_{4}$ and 0.3 volume of $0.1 \mathrm{M} \mathrm{Na}_{2} \mathrm{HPO}_{4}$. The reaction was initiated by $10 \mu \mathrm{l}$ of $100 \mathrm{mM}$ 1-chloro2,4-dinitrobenzene (CDNB) substrate. The CDNB was dissolved in $95 \%$ ethanol at a concentration of $100 \mathrm{mM}$. After a $90 \mathrm{sec}$ incubation at $37^{\circ} \mathrm{C}$, the optical density was measured at $340 \mathrm{~nm}$ every $30 \mathrm{sec}$ for $90 \mathrm{sec}$ with a SmartSpec 3000 Spectrophotometer (Bio-Rad, France). Three independent experiments were carried out using three independent batches of S9 fraction.

\section{Statistical analysis}

The experiments were repeated 3 times in different weeks in triplicate $(n=9)$ unless otherwise specified. All data are presented as the mean \pm standard error (S.E.M.). Statistical differences were determined by an unpaired Student $t$-test using significant levels of $\left.\mathrm{p}<0.01{ }^{* * *}\right)$ and $\mathrm{p}<0.05(*)$. For the study of cytochromes and GST 
activity a Student $t$-test was performed using VisualStat ${ }^{\circledR}$ Professional 2003 (Visualstat Computing, USA). This study made it possible to compare the different treatments.

\section{Results}

In total, five plant extracts were studied as medicinal mixtures (Table 1), verified to be nontoxic on the cell lines at $2 \%$. These extracts were then incubated with cells before and after xenobiotic intoxications, either by $\mathrm{R}$ (Figure 1, 2) or with the BPA-Az mixture (Figure 3), applied at the related LC50 which was the first one to be determined.

\section{On human embryonic cells}

Figure 1 presents the first screening and characterization of the protective and curative effects (curves and table, respectively) of the 5 plant extracts on embryonic human E293 cells, which were intoxicated by R. It is an efficient toxicant since the corresponding LC50 measured is $\sim 0.03 \%$ over only $24 \mathrm{~h}$. This represents our model of intoxication of less differentiated and sensitive cells. Each panel of Figure 1, A to 1E, represents the effect of one plant extract incubated before or after the intoxication by $\mathrm{R}$, according to the time-sequence indicated by different coloured lines in the frame. Dig2 was the most protective, preventing $32-34 \%$ of $\mathrm{R}$ toxicity in


Figure 1 Preventive and curative effects of various plant extracts on embryonic 293 human cells intoxicated by the herbicide Roundup. The viability is measured by the mitochondrial succinate dehydrogenase activity in comparison to non-treated cells (M). Cells were grown in EMEM with $10 \%$ serum during $48 \mathrm{~h}$, up to $80 \%$ confluence in 48 -well plates, and then exposed to different treatments. In the frame after A-E, each letter indicates successively $24 \mathrm{~h}$ of the following treatments: Medium alone (M) equivalent to Plant extract alone, Roundup alone ( $R$ at $0.03 \%, \sim L C 50)$ or with various plant extracts at $2 \%(X)$ which are for fig. A, B, C, D, E: Dig1, Dig2, Circ1, Sp1, Uro1. In Fig. F, the corresponding protective efficiencies (from LC50 considered as zero efficiency) are calculated by the formulations at 24 h: 100 - [(100 - XR viability) $\times 100 /(100-R$ viability) $]$ and at 48 h: $100-[(100-$ XXR viability $) \times 100 /(100-R$ viability) and are represented by new colors for each product. In the table below, curative effects are calculated for $24 \mathrm{~h}$ by the difference RX - RM or RXX - RMM for 48 h. All experiments were repeated 3 times in triplicates. Statistically significant differences are calculated in comparison to $\mathbf{M}$ or to the LC50 for fig. $\mathbf{F}$, and by a student t-test $\mathrm{p}<0.01\left(^{* *}\right)$ and $\mathrm{p}<0.05\left(^{*}\right)$. 


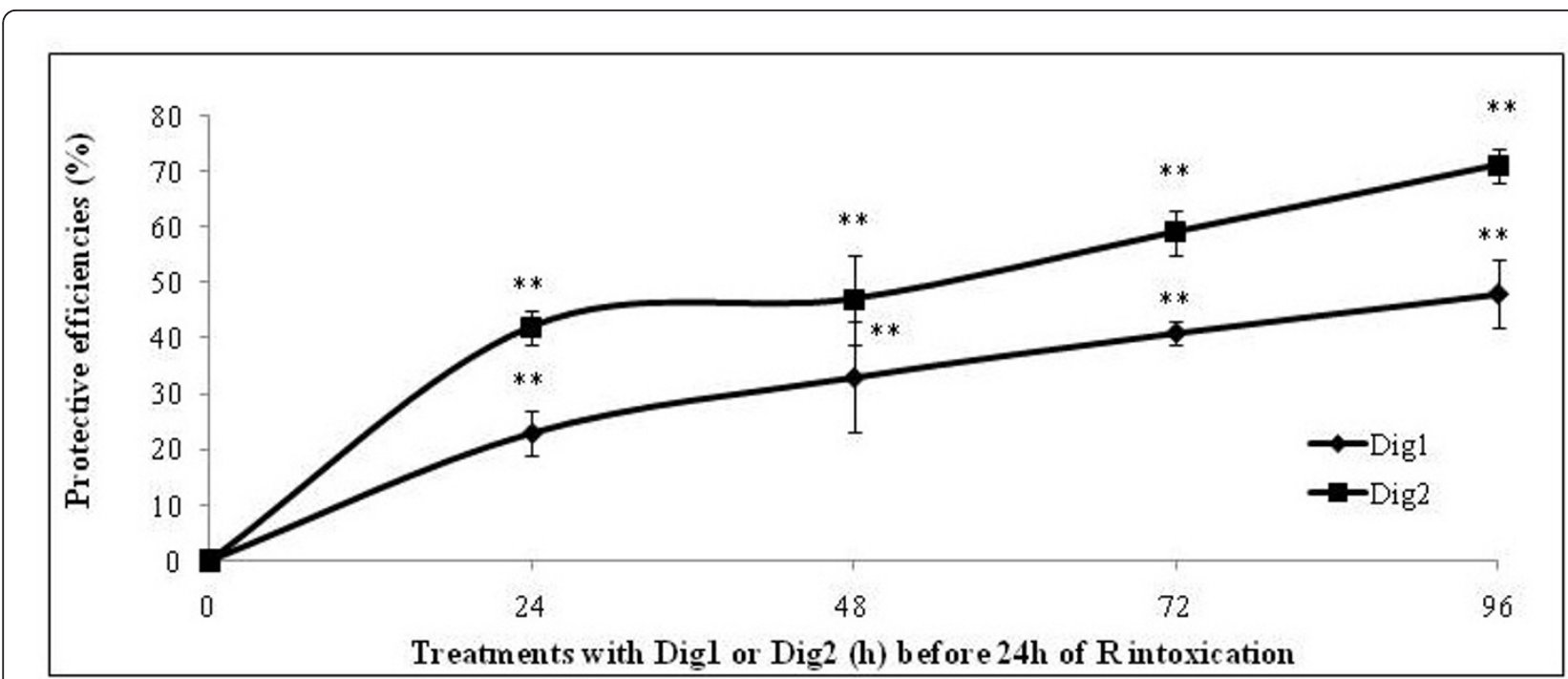

Figure 2 Protective efficiencies of Dig1 and Dig2 on HepG2 cells intoxicated by Roundup. These are calculated as indicated in figure 1 . Cells were exposed first to Dig1 or Dig2 at 2\% during 0-96 h, and then intoxicated $24 \mathrm{~h}$ with R (at 0.0175\%, LC50) or not (control 100\%) before this viability measurement.

24-48 h (visible in the upper curve, Figure 1F). Circ1 was comparable but needed a $48 \mathrm{~h}$ exposure; most of these effects are dose or time-dependent. Dig1, Sp1 and Uro1 presented a second range protective efficiency reaching 25-28\% within $48 \mathrm{~h}$. Curative effects of all these products after $\mathrm{R}$ intoxication were more difficult to highlight, and visible essentially after $24 \mathrm{~h}$ for $\mathrm{Sp} 1$ and Uro1 treatments, with $20 \%$ of cells more viable.

\section{On human HepG2 hepatocytes}

Dig1 and Dig2 were chosen as mixtures in order to focus on human HepG2 in Figure 2, because their compounds have active effects on the digestive sphere, according to the bibliography and the medical indications. We first demonstrated again that $\mathrm{R}$ was very toxic on such cells, with a LC50 around $0.0175 \%$ (175 ppm) over a 24 h period. Dig2 presented again the best protective effects, and

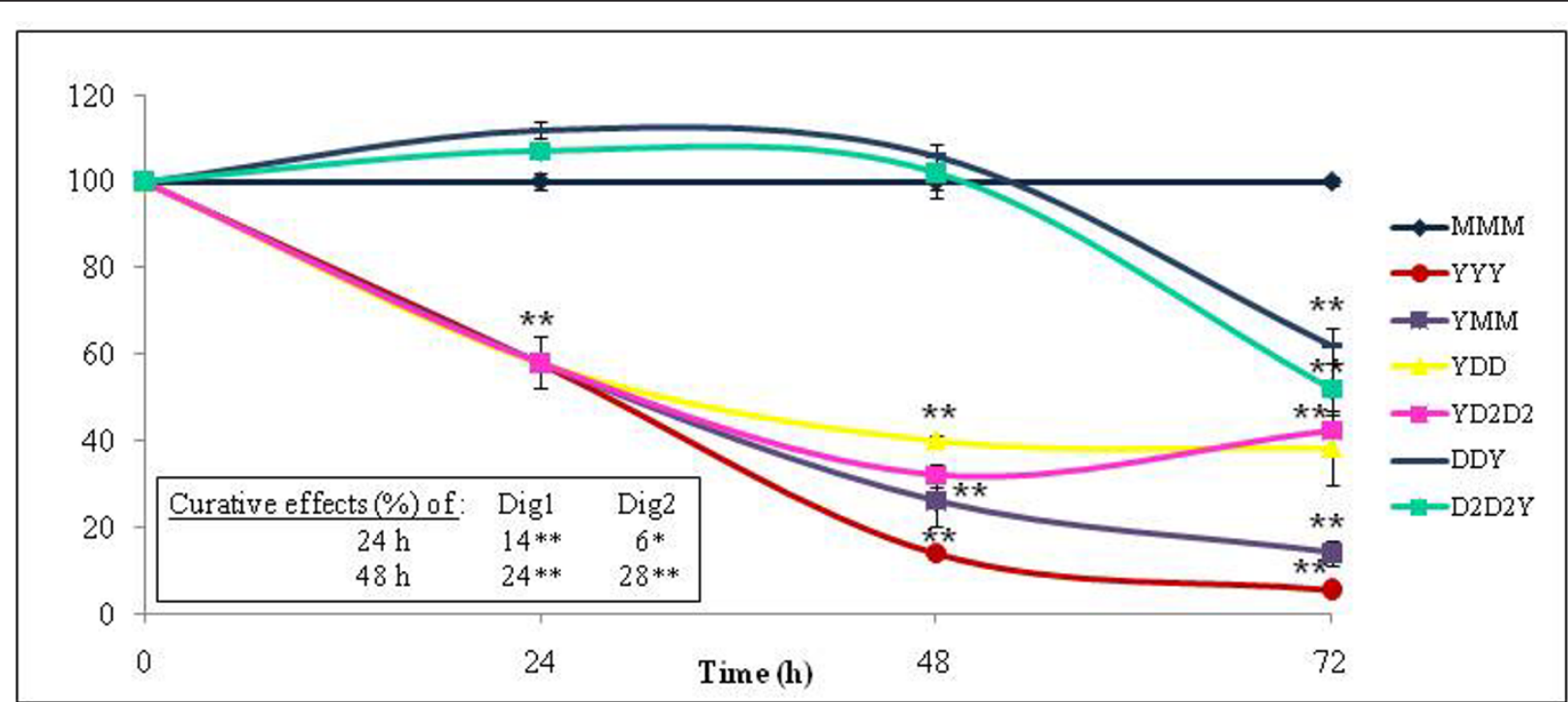

Figure 3 Preventive and curative effects (\% according to time) of Dig1 and Dig2 on HepG2 cells intoxicated by the mixture bisphenol A and Atrazine. The protocol and calculations are similar to figure 1. In the legend on the right, each letter indicates successively $24 \mathrm{~h}$ of the following treatments: Medium alone (M) equivalent to Plant extract alone, mixture of pollutants BPA+Az (called Y at $200 \mu M$ each, LC50), or with Dig1 (D) or Dig2 (D2) at 2\%. In the table in frame, the curative effects are indicated in \%. 
Dig1 was representative of the second class, as identified above. We then focused on protective actions of plant extracts over longer periods of up to $96 \mathrm{~h}$, this taking place before the intoxication by $\mathrm{R}$ (mixture of $\mathrm{G}$ with adjuvants) over a $24 \mathrm{~h}$ period. A strong time-dependent hepato-protective effect was then highlighted for both compounds, reaching at least $71 \%$ within 96 h for Dig2 or $48 \%$ for Dig1.

Then the next goal was to check the specificity of the hepatoprotective effects with another mixture of xenobiotics, equally composed of BPA and Az (Figure 3). The mixture was also demonstrated to be toxic for HepG2 cells with a LC50 of $200 \mu \mathrm{M}$ for each compound. Surprisingly, both agents had similar properties, no protective effects were highlighted: curves DDY and D2D2Y were equal to $\mathrm{Y}$ alone. However, mild timedependent curative effects (up to $28 \%$ ) were demonstrated for the first time.

In order to detail the specific mechanisms of protective and curative effects, we tried to find out first whether Dig1 and Dig2 were able to prevent G entry into HepG2 cells (Figure 4). R is composed of $G$ and adjuvants, as already indicated. This was measured by the entry of labelled $G\left(G^{*}\right)$ at non toxic doses, as a tracer in presence or absence of these plant extracts.
Firstly, we observed that $\mathrm{G}^{*}$ (alone or with $\mathrm{R}$ adjuvants) entered HepG2 cells in a time-dependent manner (about twice as much in 2 days than in one: $G^{*} / G^{*}$ higher than $\mathrm{G}^{*} / \mathrm{M}$, or $\mathrm{RG}^{*} / \mathrm{RG}^{*}$ higher than $\mathrm{RG} / \mathrm{M}$, statistical differences indicated in bold lines). It was quite clear that the plant extracts could not modify $\mathrm{G}^{*}$ penetration by themselves over $24 \mathrm{~h}$, either before or after exposure (no difference between (D or D2)/G* or $\mathrm{RG}^{*}$ and $M /\left(G^{*}\right.$ or $\left.R G^{*}\right)$; and no difference between $G^{*} / M$ and $G^{*} /(D$ or $\left.D 2)\right)$. However, they apparently lightly promoted $G^{*}$ penetration into cells by $\sim 1.5$, but only when $\mathrm{R}$ adjuvants were present (statistical comparisons in dotted lines). But $\mathrm{R}$ adjuvants did not significantly influence $G$ penetration over $24 \mathrm{~h}$, they could even retain it temporarily, but this effect needs to be confirmed.

As Dig1 and Dig2 do not appear to have developed their protective effects outside cells on $G$ and $R$ entry into cells, we measured Dig2 intracellular actions at three independent endpoints, two major cytochromes P450 induced by xenobiotics, CYP1A2 and CYP3A4 (Figure 5), and GST (Figure 6). We focused on Dig2 since Dig1 had previously been studied, although with another $\mathrm{R}$ formulation mixture [9], and because Dig2 presented the most important protective or curative

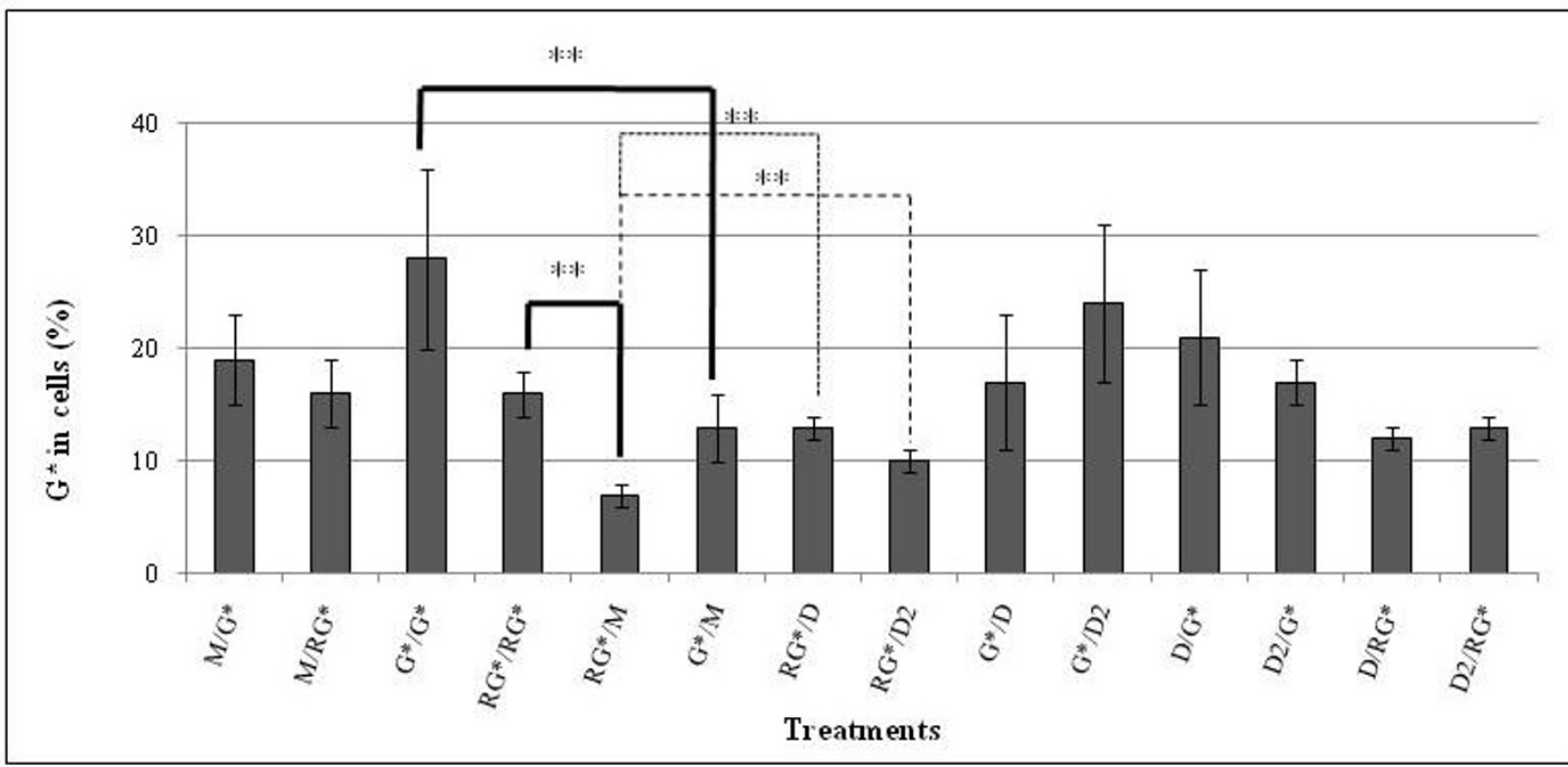

Figure $4{ }^{14} \mathrm{C}$-glyphosate entered in HepG2 cells in presence or absence of Roundup and Dig1 or Dig2. Cells were grown in 24-well plates and other conditions and calculations are explained in figure $1 .{ }^{14} \mathrm{C}$-Glyphosate $\left(\mathrm{G}^{*}\right)$ entry in cells was measured in $\%$ by counting the radioactivity in pellets, and taking into account the mortality $(20 \%)$ according to the formula $\left[G^{*}\right.$ in pellets $\left.\times(120 / 100)\right] \times 100 / G^{*}$ in supernatants. The treatments were changed every $24 \mathrm{~h}$, cells were treated $48 \mathrm{~h}$ : for instance, medium (M) for the first day and $\mathrm{G}^{*}$ for the second day will be indicated $\mathrm{M} \mathrm{G}^{*}$. $\mathrm{G}^{*}$ is at a final concentration of $0.266 \mu \mathrm{mol} / \mathrm{ml}$ for a specific activity of $55 \mu \mathrm{Ci} / \mu \mathrm{mol}$, corresponding to the quantity of $\mathrm{G}$ in $0.01 \%$ of $R$ (nontoxic in these conditions). Also, $G^{*}$ was a tracer in a $0.01 \%$ dilution of $R\left(R G^{*}\right)$, including the adjuvants; the $G$ final concentration was still nontoxic. Dig1 (D) or Dig2 (D2) at 2\% or medium alone (M) were incubated during the first or the second day to study preventive or curative effects. The only statistical differences between two treatments are indicated by ** $(p<0.01)$. 


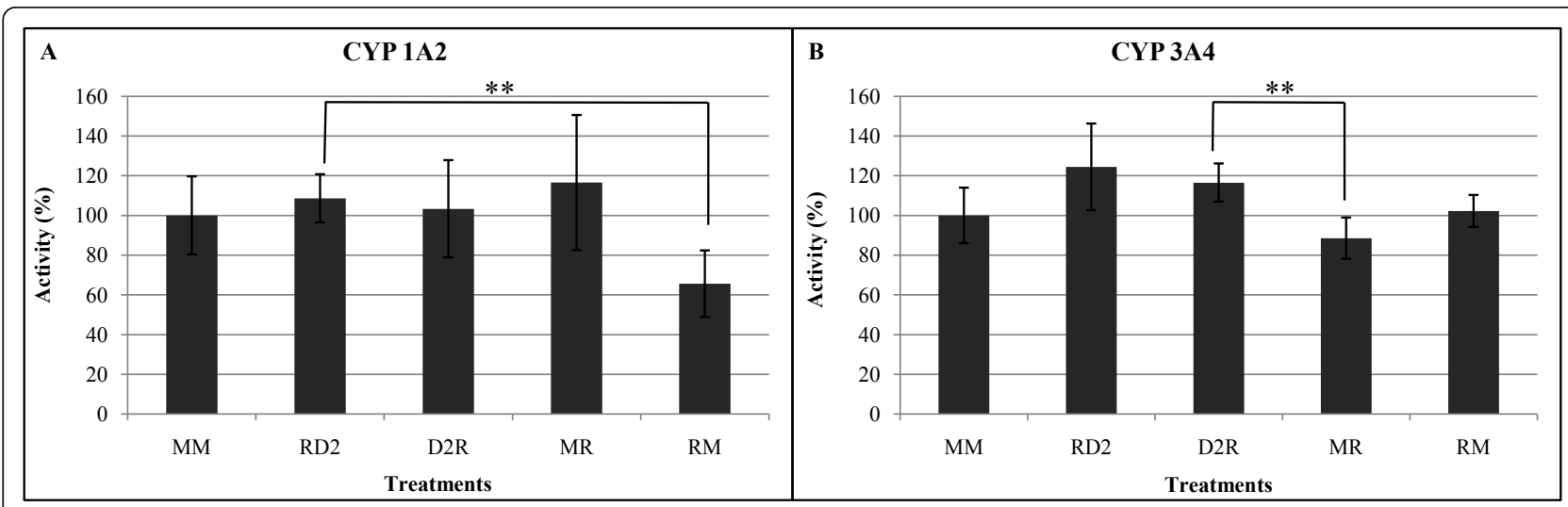

Figure 5 Effects of Roundup $\mathbf{4 5 0}$ and Dig2 on cytochrome activities in HepG2 cells. Results are presented in arbitrary units of cytochromes CYP1A2 (5A) and CYP3A4 (5B) activities. Cells were grown in flasks, other conditions and calculations are explained in figure 1. On the abscissa, each letter (M, R, D2) indicates $24 \mathrm{~h}$ of successive cell exposures to the corresponding conditions (Medium alone, Roundup, Dig2) and treatments are changed each $24 \mathrm{~h}$. R was applied at $0.0157 \%$ (non cytotoxic dose in these conditions) and Dig2 at 2\%.

effects depending on the model (Figure 1, 2, 3). There were no major modifications of the cytochromes P450 with the $\mathrm{R}$ formulation used in this research, however $\mathrm{R}$ appeared to reduce significantly the CYP1A2 activity by $40 \%$ (Figure 5A), and this was restored by Dig2 applied after $\mathrm{R}$ (curative effect). No preventive effect was highlighted through CYP1A2 regulation, but a mild inhibition (15\%) of CYP3A4 was totally restored (Figure 5B). On the other hand, Dig2 did not seem to modulate GST (Figure 6), either in a preventive or curative manner, nor did it modulate the $\mathrm{R}$ used in the present study in a significant manner.

\section{Discussion}

First of all, the present work highlighted the toxic effects of an $\mathrm{R}$ formulation on human cell lines, whereas $\mathrm{R}$ is the most widely used herbicide worldwide. As previously demonstrated, R had cytotoxic effects on embryonic [10] and hepatic cells $[8,9]$. Here we found that the R formulation used had a LC50 of $0.0175 \%$ (175 ppm) for HepG2,

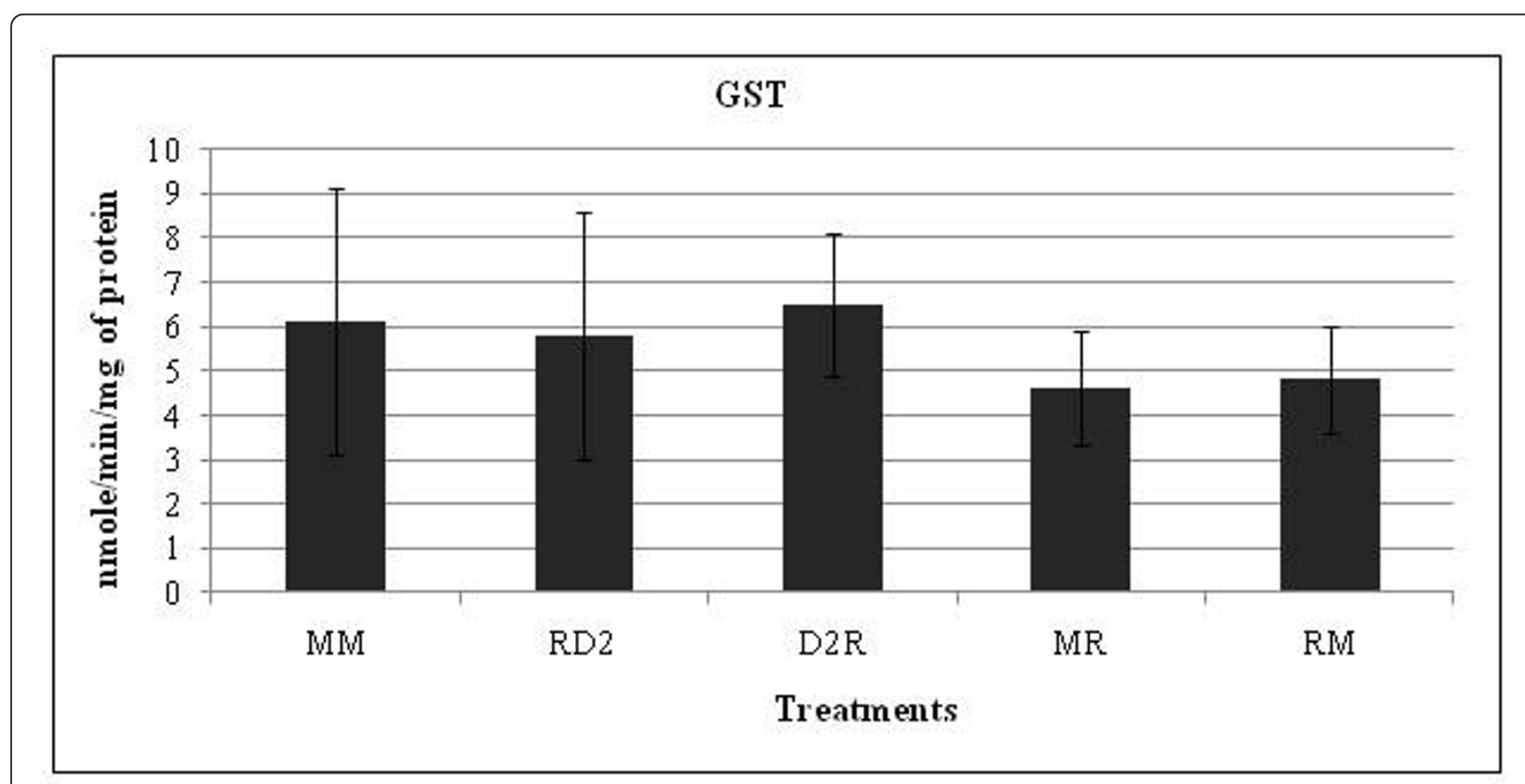

Figure 6 Effects of Roundup 450 and Dig2 on glutathione S-transferase activity in HepG2 cells. Cells were grown and treatments performed as explained in figure 5. 
ranging between 57-114 times below agricultural levels (1-2\%). The LC50 is also 2.3 times below the maximum level of residues authorized in some genetically modified R-tolerant feed, (400 ppm, [34]). The value of the LC50 demonstrated here is even around 5 times less, if we calculate it from $\mathrm{G}$ absolute concentration, and not from a dilution of the commercial product considered as $100 \%$. BPA and $\mathrm{Az}$ were used at $200 \mu \mathrm{M}$ each, which represents approximately the LC50 in short term specific conditions relative to these cells. As this is the case for example with the urine levels of contaminated people (around $16 \mathrm{nM}$ for BPA [35], or $2 \mathrm{nM}$ for Az, [36]. However, such compounds are either lipophilic or have lipophilic residues, which implies that they will bioaccumulate in tissues. Moreover BPA is known to leak from cans (around $2 \mu \mathrm{M}$ for instance, [37], and $876 \mu \mathrm{M}$ may form DNA adducts in vivo in mice [38]. As far as Az is concerned, it disrupts oocyte maturation at $200 \mu \mathrm{M}$ [39], and from $\mu \mathrm{M}$ levels, it modifies estrogen synthesis in sensitive target tissues [40]. We also assessed cell viability after BPA-Az intoxication. These products were previously demonstrated as being toxic in HepG2 separately, and in placental JEG3 cells, but they were also capable of disrupting crucial enzymes for cell metabolism or endocrine regulation $[6,41,42]$. We found that the cell sensitivities depended on the nature of the xenobiotic mixtures and the types of cells used. $\mathrm{R}$ was the most toxic of all in these conditions.

Few studies, if any, deal with the prevention and detoxification of contaminants in mixtures taking into account the synergistic effects [6] they may present in the environment. In a similar manner, several plants alone were known for preventive or curative actions, however their synergistic potential was also mostly ignored at a molecular level. Here we highlighted that all the chosen plant mixtures (Circ1, Dig1, Dig2, Sp1, Uro1) may prevent quite effectively embryonic cell mortality up to $1 / 3$ to $1 / 4$ within 1-2 days only, if administered before the intoxication; although with different kinetics demonstrating cellular specific effects. The anti-pollutant effect is greater during prevention than if the plants are administered after toxicants (1/5 of recovery only with two compounds, $\mathrm{Sp} 1$ and Uro1), probably because the lethal effects of $\mathrm{R}$ are amplified with time [10]. Sambucus nigra in Sp1 or Solidago virgaurea in Uro1 are known for their protective cell actions, overall against oxidative molecules $[22,43,44]$ that could be present in R formulation. Similarly, the plant protective properties are also time-dependant. The specificity of action was better confirmed when the protection efficiency reached up to $71 \%$ with hepatoprotective agent Dig2 applied on hepatocyte-derived cells. This was true even if HepG2 cells were about 1.7 more sensitive to intoxication than embryonic cells in this case (from LC50 comparisons for R). We also deduced the specificity of plant mixtures actions thanks to the fact that the effects were different with another type of pollutants, for instance, the curative effects reached 28\% for Dig 2 after HepG2 intoxication by BPA-Az. Therefore, it seems that oxidative damage protection by plant extracts cannot explain all the effects. Moreover, with $\mathrm{R}$ tested on other human cells, we know that numerous enzymes were reached, such as adenylate kinase, caspases 3/7 [7], aromatase, and even steroid receptors [8].

To approach the molecular actions of the most hepatoprotective compounds, we tested the importance of an extracellular trap of contaminants using the plant extracts. We also made this assumption because the plant extracts did not have any cytotoxicity by themselves in our conditions. A major extracellular trapping was almost excluded by the fact that a labelled contaminant was penetrating the cells with or without the $\mathrm{R}$ formulation. The plant extracts together with the $R$ adjuvants might have even helped $G$ penetration. It was deduced that the effects were mostly intracellular. Some G metabolites may even have been already excreted, and this does not exclude a bioaccumulation of contaminants over longer periods of time.

Dig2 had the major protective and curative effects on HepG2; it contains Chelidonium majus, which is also known to reduce transaminase-enhanced levels by toxicants in vivo $[45,46]$. Moreover, Dig2 also contains extracts of Raphanus sativus, which is mainly composed of glucosinolates. These are transformed in part into indole-3-carbinol, which in turn induces enzymes of hepatic phase I metabolism of xenobiotics, such as cytochrome P450 [47]. This may contribute to the elimination of toxicants and could therefore prevent their adverse effects, at least in part. Several studies have indicated that HepG2 cells retained the activities of the drug metabolism phase I and phase II enzymes involved in activation and detoxification of genotoxic carcinogens $[48,49]$. As a matter of fact, Dig2 restored CYP1A2 or prevented CYP3A4 depression, following $\mathrm{R}$ intoxication in the present work. Other cytochromes like human hepatic CYP17 are also inhibited by pollutants such as BPA and nonylphenol [50,51]. Altogether this shed a new light on the intracellular actions of these plant extracts but other enzymatic impacts cannot be excluded. We thus measured GST in HepG2, but its absence of modulation by Dig2 or R underlines again the specificity of intoxication/detoxification pathways.

In conclusion, we demonstrated specific and cytotoxic effects of R and BPA-Az on human hepatocytes-derived and embryonic cell lines. This was for $\mathrm{R}$ at doses far below those used in agriculture and at levels of residues present in some genetically modified food and feed. In these conditions, cell mortality induced by $\mathrm{R}$ can be almost entirely prevented in HepG2 cells within 48 h by Sevene Pharma products Dig1 and Dig2. The latter also 
had some curative effects after BPA-Az intoxication. Similarly Circ1, Sp1 and Uro1, had some protective or curative effects depending on the cells and the toxicants. The pathways involved comprise at least CYP1A2 and CYP3A4 after $R$ and Dig2 actions, thus the defense systems of the cells are modulated. Besides promising actions that need to be confirmed in vivo, these products provide altogether a useful tool to better understand the intoxication/detoxification pathways reacting in case of physiological contamination by xenobiotics.

\section{Acknowledgements}

This study was supported by Sevene Pharma Company. C.G. and E.C. received fellowships from the Conseil Regional de Basse-Normandie and the CRIIGEN (Committee for Independent Research and Information on Genetic Engineering). I C.G. fellowship was also supported by the Ethic Committee of Léa Nature Group/Jardin Bio for which we are very grateful. Part of the work was accomplished at C.Ris Pharma (for the Cytochromes and GST study). We thank the Foundations Human Earth and Denis Guichard for structural support. We thank Herrade Hemmerdinger for proofreading the English version of the manuscript.

\section{Author details}

'Laboratory of Biochemistry EA2608, Institute of Biology, University of Caen, France. ${ }^{2}$ CRIIGEN and Risk Pôle MRSH, CNRS, University of Caen 14032, France. ${ }^{3}$ Sevene Pharma, 30170 Monoblet, France.

\section{Authors' contributions}

CG carried out the cellular, biochemical and molecular studies, participated in drafting the manuscript. $\mathrm{CL}$ participated in plant extracts conception and discussions. CDL directed formulations and assessments of medicinal plant extracts Circ1, Dig1, Dig2, Sp1 and Uro1 for Sevene Pharma. RM and EC reproduced and helped the cellular experiments. CT participated in the methodological and protocol advices, and discussions. GES conceived the study, the final version of the manuscript, was responsible for the design of the work and was the scientific head and coordinator. All authors read and approved the final manuscript.

\section{Competing interests}

The authors declare that they have no competing interests. The developments of plant extracts in Sevene Pharma were performed completely independently of their biological assessments. The scientists in the University of Caen in charge of the assessment of xenobiotics or plant extracts declare no financial or other interests in the development of these products.

Received: 15 June 2010 Accepted: 20 January 2011

Published: 20 January 2011

\section{References}

1. IFEN: Report on pesticides in waters: Data 2003-2004. Institut Français de I'Environnement, Orléans, France; 2006:5:15-20, Dossier.

2. Takahashi M, Horie M, Aoba N: Analysis of glyphosate and its metabolite, aminomethylphosphonic acid, in agricultural products by HPLC. Shokuhin Eiseigaku Zasshi 2001, 42:304-308.

3. Spiroux de Vendômois J, Roullier F, Cellier D, Séralini GE: A comparison of the effects of three GM corn varieties on mammalian health. Int. J. Biol. Sci 2009, 5:706-726.

4. Williams GM, Kroes R, Munro IC: Safety evaluation and risk assessment of the herbicide Roundup and its active ingredient, glyphosate, for human. Regul. Toxicol. Pharmacol 2000, 31:117-165.

5. Richard S, Moslemi S, Sipahutar H, Benachour N, Séralini GE: Differential effects of glyphosate and Roundup on human placental cells and aromatase. Environ. Health Perspec 2005, 113:716-720.

6. Benachour N, Moslemi S, Sipahutar H, Séralini GE: Cytotoxic effects and aromatase inhibition by xenobiotic endocrine disrupters alone and in combination. Toxicol. Appl. Pharmacol 2007, 222:129-140.
7. Benachour N, Séralini GE: Glyphosate formulations induce apoptosis and necrosis in human umbilical, embryonic, and placental cells. Chem. Res. Toxicol 2009, 22:97-105.

8. Gasnier C, Dumont C, Benachour N, Clair E, Chagnon MC, Séralini GE: Glyphosate-based herbicides are toxic and endocrine disruptors in human cell lines. Toxicol 2009, 262:184-191.

9. Gasnier C, Benachour N, Clair E, Travert C, Langlois F, Laurant C, Decroix Laporte C, Séralini GE: Dig1 protects against cell death provoked by glyphosate-based herbicides in human liver cell lines. J. Occup. Med. Toxicol 2010, 5:29-41.

10. Benachour N, Sipahutar H, Moslemi S, Gasnier C, Travert C, Séralini GE: Time- and Dose-dependent effects of Roundup on human embryonic and placental cells. Environ. Contam. Toxicol 2007, 53:126-133.

11. Urani C, Doldi M, Crippa S, Camatini M: Human-derived cell lines to study xenobiotic metabolism. Chemosphere 1998, 37:2785-2795.

12. Knasmüller S, Mersh-Sundermann V, Kevekordes S, Darroudi F, Huber WW Hoelzl C, Bichler J, Majer BJ: Use of human-derived liver cell lines for the detection of environmental and dietary genotoxicants; current state of knowledge. Toxicology 2004, 198:315-328.

13. Westerink WM, Schoonen WG: Cytochrome P450 enzyme levels in HepG2 cells and cryopreserved primary human hepatocytes and their induction in HepG2 cells. Toxicol. In Vitro 2007, 21:1581-1591.

14. Bu-Abbas A, Clifford MN, Walker R, loannides C: Contribution of caffeine and flavanols in the induction of hepatic phase II activities by green tea. Food Chem. Toxicol 1998, 36:617-621.

15. Gebhardt R: Antioxydative, antiproliferative and biochemical effects in HepG2 cells of a homeopathic remedy and its constituent plant tinctures tested separately or in combination. Drug Res 2003, 12:823-830.

16. Hikino H, Kiso Y, Wagner H, Fiebig M: Antihepatotoxic actions of flavonolignans from Silybum marianum fruits. Planta Medica 1984 50:248-250.

17. Lieber CS, Leo MA, Ren C, DeCarli LM: Silymarin retards the progression of alcohol-induced hepatic fibrosis in baboons. J. Clin. Gastroenterol 2003, 37:336-339.

18. Li RZ, Pei HP, Ji XJ: Antimutagenic activity and metabolic transformation of ranunculin by rat liver microsomes. Yao Xue Xue Bao 1993, 28:481-485.

19. Pavlica S, Gebhardt R: Protective effects of ellagic and chlorogenic acids against oxidative stress in PC12 cells. Free Radic. Res 2005, 39:1377-1390.

20. Banno N, Akihisa T, Tokuda H, Yasukawa K, Higashihara H, Ukiya M, Watanabe K, Kimura Y, Hasagawa J, Nishino H: Triterpene acids from the leaves of Perilla fructescens and their anti-inflammatory and antitumorpromoting effects. Biosci. Biotechnol. Biochem 2004, 68:85-90.

21. Tunon $\mathrm{H}$, Olavsdotter C, Bohlin L: Evaluation of anti-inflammatory activity of some Swedish medicinal plants. Inhibition of prostaglandin biosynthesis and PAF-induced exocytosis. J. Ethnopharmacol 1995, 48:61-76.

22. Apati P, Szentmihalyi K, Kristo ST, Papp I, Vinkler P, Szoke E, Kery A: Herbal remedies of Solidago correlation of phytochemical characteristics and antioxydative properties. J. Pharm. Biomed. Anal 2003, 32:1045-1053.

23. Thiem B, Goslinska O: Antimicrobial activity of Solidago virgaurea L. from in vitro cultures. Fitoterapia 2002, 73:514-516.

24. Fukuda K, Hibiya Y, Mutoh M, Koshiji M, Akao S, Fujiwara H: Inhibition of activator protein 1 activity by berberine in human hepatoma cells. Planta Medica 1999, 65:381-383.

25. Janbaz KH, Gilani AH: Studies on preventive and curative effects of berberine on chemical-induced hepatotoxicity in rodents. Fitoterapia 2000, 71:25-33

26. Lin SC, Chung TC, Lin CC, Ueng TH, Lin YH, Lin SY, Wang LY: Hepatoprotective effects of Arctium lappa on carbon tetrachloride- and acetaminophen-induced liver damage. Am. J. Chi. Med 2000, 28:163-173.

27. Lin SC, Lin CH, Lin CC, Lin YH, Chen CF, Chen IC, Wang LY: Hepatoprotective effects of Arctium lappa Linne on liver injuries induced by chronic ethanol consumption and potentiated by carbon tetrachloride. J. Biomed. Sci 2002, 9:401-409.

28. Trojanova I, Rada V, Kokoska L, VIkova E: The bifidogenic effect of Taraxacum officinale root. Fitoterapia 2004, 75:760-763.

29. Seo SW, Koo HN, An HJ, Kwon KB, Lim BC, Seo EA, Ryu DG, Moon G, Kim HY, Kim HM, Hong SH: Taraxacum officinale protects against cholecystokinin-induced acute pancreatitis in rat. World J. Gastroenterol 2005, 11:597-599. 
30. Mosmann T: Rapid colorimetric assay for cellular growth and survival: application to proliferation and cytotoxicity assays. J. Immunol. Meth 1983, 65:55-63.

31. Denizot F, Lang R: Rapid colorimetric assay for cell growth and survival Modification to the tetrazolium dye procedure giving improved sensitivity and reliability. J. Immunol. Meth 1986, 89:271-277.

32. Auvray $P$, Sourdaine $P$, Moslemi $S$, Séralini GE, Sonnet $P$, Enguehard $C$, Guillon J, Dallemagne P, Bureau R, Rault S: MR 20492 and MR 20494: two indolizinone derivatives that strongly inhibit human aromatase. J. Ster. Biochem. Mol. Bio 1999>, 70:59-71.

33. Habig WH, Pabst MJ, Jacoby WB: Glutathione S-transferases. The first enzymatic step in mercapturic acid formation. J. Biol Chem 1974, 249:7130-7139.

34. U.S EPA: Environmental Protection Agency: Glyphosate; notice of filing a pesticide petition to establish a tolerance for a certain pesticide chemical in or on food. Fedral Register Environment Documents 2006.

35. Galloway T, Cipelli R, Guralnick J, Ferrucci L, Bandinelli S, Corsi AM: Daily Bisphenol A Excretion and Associations with Sex Hormone Concentrations: Results from the InCHIANTI Adult Population Study. Environ Health Perspect 2010.

36. Curwin BD, Hein MJ, Barr DB, Striley C: Comparison of immunoassay and HPLC-MS/MS used to measure urinary metabolites of atrazine, metolachlor, and chlorpyrifos from farmers and non-farmers in lowa. J Expo Sci Environ Epidemiol 2010, 20:205-12.

37. Bisphenol A: Toxic Plastics Chemical in Canned Food. [http://www.ewg. org/reports/bisphenola].

38. Izzotti A, Kanitz S, D'Agostini F, Camoirano A, De Flora S: Formation of adducts by bisphenol $\mathrm{A}$, an endocrine disruptor, in DNA in vitro and in liver and mammary tissue of mice. Mutat Res 2009, 679:28-32.

39. Casas E, Bonilla E, Ducolomb Y, Betancourt M: Differential effects of herbicides atrazine and fenoxaprop-ethyl, and insecticides diazinon and malathion, on viability and maturation of porcine oocytes in vitro. Toxicol In Vitro 2010, 24:224-30.

40. Holloway AC, Anger DA, Crankshaw DJ, Wu M, Foster WG: Atrazineinduced changes in aromatase activity in estrogen sensitive target tissues. J Appl Toxicol 2008, 28:260-70.

41. Schoonen WG, de Roos JA, Westerink WM, Débiton E: Cytotoxic effects of 110 reference compounds on HepG2 cells and for 60 compounds on HeLa, ECC-1 and CHO cells. II mechanistic assays on NAD(P)H, ATP and DNA contents. Toxicol In Vitro 2005, 19:491-503.

42. Jondeau A, Dahbi L, Bani-Estivals MH, Chagnon MC: Evaluation of the sensitivity of three sublethal cytotoxicity assays in human HepG2 cell line using water contaminants. Toxicology 2006, 226:218-228.

43. Janbaz KH, Saeed SA, Gilani AH: Protective effect og rutin on paracetamol- and $\mathrm{CCl}_{4}$-induced hepatotoxicity in rodents. Fitoterapia 2002, 73:557-563.

44. Ovesna Z, Kozics K, Slamenova D: Protective effects of ursolic acid and oleanolic acid in meukemic cells. Mutat. Res 2006, 600:131-137.

45. Mitra S, Gole M, Samadjar K, Sur RK, Chakraborty BN: Antihepatotocix activity of Chelidonium majus. Int. J. Pharmacognosy 1992, 30:125-128

46. Biswas SJ, Bhattacharjee N, Khuda-Bukhsh AR: Efficacy of a plant extract (Chelidonium majus L.) in combating induced hepatocarcinogenesis in mice. Food Chem. Toxicol 2007, 46:1474-1487.

47. McDanell R, McLean AEM: Chemical and biological properties of indole glucosinolates (glucobrassicins): A review. Food Chem. Toxicol 1987, 26:59-70.

48. Wiebel FJ, Lambiotte M, Singh J, Summer KH, Wolff T: Expression of carcinogen-metabolizing enzymes in continuous cultures of mammalian cells. Biochemicals Basis of Chemical Carcinogenesis, Raven Press, New York; $1984,77-88$.

49. Knasmüller S, Parzefall W, Sanyal R, Ecker S, Schwab C, Uhl M, MershSundermann V, Williamson G, Hietsch G, Langer T, Darroudi F, Natarajan AT: Use of metabolically competent human hepatoma cells for the detection of mutagens and antimutagens. Mut. Res 1998, 402:185-202.

50. Niwa T, Fujimoto M, Kishimoto K, Yabusaki Y, Ishibashi F, Katagiri M: Metabolism and interaction of bisphenol $\mathrm{A}$ in human hepatic cytochrome P450 and steroidogenic CYP17. Biol Pharm Bull 2001, 24:1064-1067.

51. Niwa T, Maekawa Y, Fujimoto M, Kishimoto K, Yabusaki Y, Ishibashi F, Katagiri M: Inhibition of human hepatic cytochrome P450s and steroidogenic CYP17 by nonylphenol. Biol Pharm Bull 2002, 25:235-238. doi:10.1186/1745-6673-6-3

Cite this article as: Gasnier et al: Defined plant extracts can protect human cells against combined xenobiotic effects. Journal of Occupational Medicine and Toxicology 2011 6:3.

\section{Submit your next manuscript to BioMed Central and take full advantage of:}

- Convenient online submission

- Thorough peer review

- No space constraints or color figure charges

- Immediate publication on acceptance

- Inclusion in PubMed, CAS, Scopus and Google Scholar

- Research which is freely available for redistribution

Submit your manuscript at www.biomedcentral.com/submit 